\title{
IMPLIKASI PENETAPAN IZIN LINGKUNGAN BAGI USAHA DAN/ATAU KEGIATAN PERTAMBANGAN
}

\author{
Ardimansyah \\ Fakultas Hukum Universitas Islam Kalimantan MAB \\ Jl. Adhyaksa No. 2 Kayutangi Banjarmasin Kalimantan Selatan \\ Email: ardimansyah.fhuniska@gmail.com
}

\begin{abstract}
Follow-up to provide protection and manage living environment is to be established PP No.27/2012 about Environmental Permitt, which implies each bussiness and/or activity must have Environmental Permitt. Environmental Permit which aims to anticipate environmental damage and pollution is now increasingly alarming, most of the work and / or other activities, including permits from coal. Then what is the provision of PP Environmental Permit in order to be able to capture and oblige each business and/or activity to have an environmental permit. How about mining business? In addition to other issues the community was involved in compiling Amdal documents. Whereas community involvement in Law Number 32/2009 concerning Environmental Protection and Management known as UUPPLH, what is the task capacity? To analyze the problems, the method used in this research is the method of Juridical-Normative. The results of this research are the existence of PP Environmental Permit was very helpful in the application process and the issuance of environmental permits and absolute hold for any business and/or activity. While coal mining and in the context of environmental protection and management, environmental permits are also required. Furthermore, the involvement of affected communities as members of the Audit Commission of Amdal is still unclear what to do. Thus it can be concluded that, the Environmental Permit applies to every business and/or activity that is required by Amdal or UKL-UPL. Environmental permit also apply to businesses and / or coal mining activities, while the community as a member of the Audit Commission of Amdal felt still unclear what the duties.
\end{abstract}

Keywords: Protection and Management of Living Enviromental, Enviromental Permitt, Bussiness and/or Activity.

\begin{abstract}
Abstrak
Ditetapkannya Peraturan Pemerintah Nomor 27 Tahun 2012 tentang Izin Lingkungan atau dikenal dengan PP Izin Lingkungan, telah mengisyaratkan setiap usaha dan/atau kegiatan harus memiliki Izin Lingkungan. Izin Lingkungan yang bertujuan untuk mengantisipasi kerusakan dan pencemaran lingkungan hidup sekarang ini sudah semakin mengkhawatirkan, akibat izin usaha dan/atau kegiatan lainnya, termasuk pula izin pertambangan batubara. Lalu bagaimanakah ketentuan PP Izin Lingkungan agar dapat menjaring dan mewajibkan bagi setiap usaha dan/atau kegiatan untuk memiliki izin lingkungan. Bagaimanakah pula terhadap usaha pertambangan? Disamping issue lain dilibatkannya masyarakat dalam menyusun dokumen amdal. Sedangkan keterlibatan masyarakat dalam Undang-Undang Nomor 32 Tahun 2009 tentang Perlindungan dan Pengelolaan Lingkungan Hidup yang lazim dikenal UUPPLH, belum jelas kapasitas tugasnya sebagai apa? Untuk menganalisis masalah-masalah di atas, maka metode yang dipakai dalam penelitian ini adalah metode Yuridis-Normatif. Hasil dari penelitian ini adalah bahwa keberadaan PP Izin Lingkungan sangat membantu dalam proses permohonan dan penerbitan izin lingkungan dan mutlak menjadi pegangan bagi
\end{abstract}


setiap usaha dan/atau kegiatan. Sedangkan pertambangan batubara dan dalam rangka perlindungan dan pengelolaan lingkungan hidup, diwajibkan pula Izin Lingkungan. Selanjutnya keterlibatan masyarakat terkena dampak sebagai anggota Komisi Penilai Amdal, masih belum jelas apa yang harus dilakukannya. Dengan demikian dapat disimpulkan bahwa, Izin Lingkungan berlaku bagi setiap usaha dan/atau kegiatan yang wajib Amdal atau UKLUPL. Izin Lingkungan juga diberlakukan terhadap usaha dan/atau kegiatan pertambangan batubara; sementara masyarakat sebagai anggota Komisi Penilai Amdal dirasakan masih belum jelas apa yang menjadi tugasnya.

Kata Kunci: Izin Lingkungan, Usaha dan/atau Kegiatan, Implikasi Anggota Komisi Penilai.

\section{LATAR BELAKANG MASALAH}

Pakar hukum Lingkungan Mas

Achmad Santosa mengatakan: substansi dalam Peraturan Pemerintah Nomor 27 Tahun 2012 tentang Izin Lingkungan, sebagian besar ternyata mengatur tentang Analisis Mengenai Dampak Lingkungan (Amdal), yakni berdasarkan total dari 75 Pasal, hanya ada 11 Pasal yang mengatur tentang Izin Lingkungan dan seyogyanyalah Peraturan Pemerintah tersebut lebih tepat tentang Amdal dan Izin Lingkungan. Lebih lanjut disinggungnya pula bahwa Peraturan Pemerintah Nomor 27 Tahun 2012 tentang Izin Lingkungan, tidak memuat pengaturan proses pencabutan izin secara detail. Padahal Undang-Undang Nomor 32 Tahun 2009 tentang Perlindungan dan Pengelolaan Lingkungan Hidup menerapkan sistem efek berantai izin lingkungan. Artinya, jika izin lingkungan dicabut, maka izin usaha dibatalkan. Dapat dikatakan secara umum bahwa keberadaan Peraturan Pemerintah Nomor
27 Tahun 2012 "merugikan" dunia usaha dan masyarakat. Peraturan tersebut bagi dunia usaha tidak menciptakan iklim investasi yang kondusif karena masih berlaku birokrasi perizinan. Sedangkan bagi masyarakat tidak memberikan ruang partisipasi dalam proses pengambilan keputusan perizinan. ${ }^{1}$

Menurut Iman Hendargo Abu Ismoyo (Deputi Bid.Tata Lingkungan Kementerian LH) bahwa Peraturan Pemerintah. Nomor 27 Tahun 2012 adalah jawaban atas masalah yang dihadapi dunia usaha terkait Izin Lingkungan. Sedangkan bagi masyarakat menurutnya justeru memberikan kesempatan 3 (tiga) kali untuk berpartisipasi dalam proses pengambilan keputusan dan penerbitan Izin Lingkungan. ${ }^{2}$

PP Izin Lingkungan pada hakekatnya merupakan tindak lanjut dari ketentuan Pasal 41 UUPPLH, mengenai

${ }^{1}$ Dalam Peraturan Pemerintah Nomor 27 Tahun 2012 tentang Izin Lingkungan Rentan di Judicial Review, www.hukumonline.com, diakses tanggal 11 Desember 2017.

${ }^{2}$ Ibid. 
izin lingkungan sebagaimana dimaksud dalam Pasal 36 sampai dengan Pasal 40 UUPPLH. Izin lingkungan dalam hal berusaha sebagaimana ketentuan Pasal 1 angka 35 UUPPLH disebutkan bahwa, yang dimaksud "Izin Lingkungan adalah izin yang diberikan kepada setiap orang yang melakukan Usaha dan/atau Kegiatan yang wajib Amdal atau UKL-UPL dalam rangka perlindungan dan pengelolaan lingkungan hidup sebagai prasyarat untuk memperoleh izin Usaha dan/atau Kegiatan".

Bunyi yang sama diulang lagi dalam Pasal 1 angka 1 PP tentang Izin Lingkungan. Penekanan wajib Amdal atau UKL-UPL bagi setiap Usaha dan/atau Kegiatan merupakan penegasan yang sangat penting dari ketentuan dalam UUPPLH, yakni dalam Pasal 22 tentang Amdal; dan Pasal 34 tentang UKL-UPL. Sedangkan Perizinan diuraikan dalam Pasal 36 yang bunyinya:

(1) Setiap usaha dan/atau kegiatan yang wajib memiliki Amdal atau UKL-UPL wajib memiliki Izin Lingkungan;

(2) Izin Lingkungan sebagaimana dimaksud pada ayat (1) diterbitkan berdasarkan keputusan kelayakan lingkungan hidup sebagaimana dimaksud dalam Pasal 31 atau rekomendasi UKL-UPL;
(3) Izin Lingkungan sebagaimana dimaksud pada ayat (1) wajib mencantumkan persyaratan yang dimuat dalam keputusan kelayakan lingkungan hidup atau rekomendasi UKL-UPL;

(4) Izin Lingkungan diterbitkan oleh Menteri, Gubernur, atau Bupati/Walikota sesuai dengan kewenangannya.

Artinya bunyi pasal di atas mengisyaratkan bahwa Izin Lingkungan harus dipenuhi lebih dahulu bagi setiap usaha dan/atau kegiatan sebelum izin lainnya diterbitkan, yang ditindaklanjuti dalam Peraturan Pemerintah.

Ketentuan yang diatur dalam UUPPLH dan PP Izin Lingkungan, umumnya mengarah kepada upaya perlindungan dan pencegahan agar lingkungan hidup dapat terhindar dari kerusakan dan pencemaran lingkungan. Sebagaimana juga peringatan yang sangat jelas tentang alam semesta yang dimuat di dalam Al-Qur'an. Peringatan Allah SWT kepada umat manusia dapat dilihat dalam Surah Ar-Ruum: 41; yang artinya:

"Telah nampak kerusakan di daratan dan di lautan disebabkan kerena perbuatan manusia, supaya Allah merasakan kepada manusia sebagian dari (akibat) perbuatan mareka agar mereka kembali".

Dapat dipahami kerusakan sebagai akibat dampak besar dan penting, dari usaha 
dan/atau kegiatan di bidang lingkungan.

Oleh karena itu harus ada ketegasan pemberlakuan peraturan di bidang lingkungan dan sumber daya alam, di antaranya:

1. Undang-Undang Nomor 41 Tahun 1999 tentang Kehutanan; jo Undang-Undang Nomor 19 Tahun 2004 tentang Penetapan Perppu Nomor 1 Tahun 2004 tentang Perubahan Atas Undang-Undang Nomor 41 Tahun 1999 tentang Kehutanan menjadi UndangUndang;

2. Undang-Undang Nomor 4 Tahun 2009 tentang Pertambangan Mineral dan Batubara;

3. Undang-Undang Nomor 32 Tahun 2009 tentang Perlindungan dan Pengelolaan Lingkungan Hidup;

4. Peraturan Pemerintah Nomor 27 Tahun 2012 tentang Izin Lingkungan;

Semua peraturan di atas adalah wujud kepedulian Pemerintah/Lembaga Negara dalam membuat aturan untuk menjaga, melestarikan, dan memberikan perlindungan lingkungan hidup dan sumber daya alam.

Selanjutnya dasar pemberian peluang kepada pihak swasta untuk turut serta memajukan perekonomian nasional, dipahami sebagai suatu langkah maju kearah percepatan pembangunan yang di fasilitasi oleh Pemerintah. Dalam rangka menggalakkan sektor usaha dan/atau kegiatan dalam pencapaian peningkatan ekonomi rakyat, dengan antara lain menyerap tenaga kerja dalam negeri/lokal baik di daerah provinsi maupun di daerah kabupaten/kota. Tidak pula dipungkiri bahwa setiap gerak pembangunan yang dijalankan, selalu membawa konsekuensi berupa dampak terhadap ekosistem lingkungan hidup.

Sehubungan dengan maksud di atas merasa perlu untuk mengkaji implikasi berkaitan dengan Izin Lingkungan, terhadap usaha dan/atau kegiatan, serta dilibatkannya masyarakat sebagai anggota tim penilai. Sebab izin lingkungan dapat diartikan sebagai tiket masuk pintu pertama untuk selanjutnya masuk kepada pintu lainnya yang dikehendaki dalam berusaha dan/atau kegiatan lainnya. Namun haruslah pula ada persetujuan masyarakat.

Dalam perkembangan sekarang ini dengan berjalannya UUPPLH, ternyata ketentuan Amdal berada satu paket dalam substansi pasal-pasalnya. Amdal masuk dalam Paragraf 5, dimuat pada Pasal 22 sampai dengan Pasal 33 UUPPLH. Ketentuan Amdal disebutkan dalam Pasal 22, berbunyi : 
(1) Setiap usaha dan/atau kegiatan yang berdampak penting terhadap lingkungan hidup wajib memiliki amdal.

(2) Dampak penting ditentukan berdasarkan kriteria:

a. Besarnya jumlah penduduk yang akan terkena dampak rencana usaha dan/atau kegiatan;

b. Luas wilayah penyebaran dampak;

c. Intensitas dan lamanya dampak berlangsung;

d. Banyaknya komponen lingkungan hidup lain yang akan terkena dampak;

e. Sifat kumulatif dampak;

f. Berbalik atau tidak berbaliknya dampak, dan/atau

g. Kriteria lain sesuai dengan perkembangan ilmu pengetahuan dan teknologi.

Ketentuan UUPPLH ini telah mengisyaratkan bahwa penyusunan dokumen amdal oleh pemrakarsa harus melibatkan masyarakat (Pasal 26 Ayat 1). Bahkan masyarakatpun dapat mengajukan keberatan atas dokumen amdal yang patut diduga merugikan pihak mereka (Pasal 26 Ayat 4). Inilah konsekuensi pentingnya ketentuan amdal agar tujuan dan masalah-masalah yang berkaitan dengan lingkungan hidup manusia dapat diminimalisir kemungkinan akan kerugian, kerusakan dan ketercemarannya.

Berdasarkan data yang disampaikan oleh Kementerian Kehutanan RI menyebutkan ada beberapa tantangan $^{3}$, yaitu:

1. 130,9 juta ha kawasan hutan, sekitar $50 \%$ nya harus dilakukan rehabilitasi, dan sebagian besar kawasan adalah wilayah open akses;

2. Degradasi hutan. Deforestrasi masih berlanjut (akibat illegal logging, kebakaran hutan, perambahan, lemahnya managemen pengelolaan hutan, dll);

3. Sekitar 48 juta masyarakat kehidupannya tergantung hutan, 10 juta miskin;

4. Ada sekitar 25.000 desa di dalam/sekitar hutan;

5. Konflik teritorial;

6. Pemanasan global.

Untuk mengurangi masalah di atas ada beberapa perangkat penyerta yang harus di lalui sebagai syarat untuk didapatkannya izin berusaha di wilayah

3 Materi Seminar Memperingati Hari Bumi 21 April 2012 di Banjarmasin, "Save Kalimantan Save Indonesia" (makalah), Oleh Kementerian Kehutanan RI. 
Negara Indonesia, yakni berupa dipenuhinya ketentuan wajib Analisis Mengenai Dampak Lingkungan (Amdal) atau Usaha Pengelolaan Lingkungan Usaha Pemantauan Lingkungan (UKLUPL). Ketentuan wajib Amdal atau UKLUPL didasarkan pada Peraturan Menteri Lingkungan Hidup Nomor 11 Tahun 2006 tentang Jenis Rencana Usaha dan/atau Kegiatan yang Wajib Dilengkapi Dengan Amdal; serta Peraturan Menteri Negara Lingkungan Hidup Nomor 13 Tahun 2010 tentang Upaya Pengelolaan Lingkungan Hidup dan Upaya Pemantauan Lingkungan Hidup dan Surat Pernyataan Kesanggupan Pengelolaan dan Pemantauan Lingkungan Hidup. Kemudian disempurnakan dengan ketentuan sekarang ini adalah berdasarkan: Peraturan Pemerintah Republik Indonesia Nomor 27 Tahun 2012 tentang Izin Lingkungan. Peraturan yang merupakan pelaksanaan dari Undang-Undang Nomor 32 Tahun 2009 tentang Perlindungan dan Pengelolaan Lingkungan Hidup.

\section{RUMUSAN MASALAH}

Rumusan masalah yang akan dibahas dalam penelitian ini adalah kepada hal yang berkaitan dengan Implikasi Penetapan Izin Lingkungan, atas usaha dan/atau kegiatan, serta implikasi persetujuan masyarakat sebagai anggota penilai, yang pada hakekatnya selalu menyangkut ekosistem lingkungan hidup dan sumber daya alam serta kehidupan manusia. Sehubungan dengan maksud tersebut maka rumusan yang akan dibahas ialah:

1. Apakah Izin Lingkungan wajib bagi setiap usaha dan/atau kegiatan?

2. Apakah Izin Lingkungan wajib pula bagi usaha dan/atau kegiatan Pertambangan?

3. Bagaimanakah peran masyarakat selaku Anggota Komisi Penilai Amdal?

\section{METODE PENELITIAN}

Metode yang dipakai dalam penelitian ini adalah metode : YuridisNormatif. Yakni peneliti akan mengumpulkan berbagai peraturan perundang-undangan. Antara lain Undang-undang di bidang lingkungan hidup, beserta dengan Peraturan pelaksana terkait Izin Lingkungan; serta ketentuan lain yang ada hubungannya dengan masalah lingkungan dan sumber daya alam.

Kesemua aturan tersebut akan dijadikan dasar untuk memecahkan persoalan yang menjadi issue masalah dalam hubungannya dengan implikasi 
Penetapan Izin Lingkungan yang

dimohonkan Pelaku Usaha dan/atau

Kegiatan, khususnya usaha dan/atau kegiatan pertambangan, serta implikasi keterlibatan masyarakat sebagai penilai sebelum izin diteerbitkan.

Oleh karena kedudukan Izin Lingkungan sangat penting, yang bertujuan untuk mengetahui apa saja manfaat dari dilibatkan wakil masyarakat sebagai pemberi persetujuan Izin Lingkungan terhadap kehidupan masyarakat sekitar, baik dari segi sosial, ekonomi, termasuk pula pembangunan pendidikan, dan kesehatan.

\section{PEMBAHASAN}

\section{Izin Lingkungan Bagi Usaha dan/atau} Kegiatan

Sebelum disebutkan pengertian Izin Lingkungan yang dimuat dalam peraturan perundangan, ada baiknya mengemukakan lebih dahulu pengertian izin pada umumnya.

Pendapat ahli hukum Belanda N.M. Spelt dan J.B.J.M. Ten Berge, mengatakan, “izin” merupakan suatu persetujuan penguasa berdasarkan undang-undang atau peraturan pemerintah untuk dalam keadaan tertentu menyimpang dari ketentuan larangan perundang-undangan. ${ }^{4}$

Menurut Prajudi Atmosudirdjo, “izin" adalah suatu penetapan yang merupakan dispensasi pada suatu larangan oleh undang-undang yang pada umumnya larangan tersebut diikuti dengan perincian syarat-syarat, kriteria, dan sebagainya yang perlu dipenuhi oleh pemohon untuk mendapatkan izin yang disertai dengan penetapan prosedur dan petunjuk pelaksanaan (juklak) kepada pejabatpejabat administrasi negara yang bersangkutan. $^{5}$

Sedangkan menurut Van Der Pot, "izin" dalam arti yang luas merupakan keputusan yang memperkenankan dilakukan perbuatan apa saja yang pada prinsipnya tidak dilarang oleh pembuat peraturan. $^{6}$

Pengertian secara umum tentang Izin dapat dikemukakan sebagai berikut, bahwa Izin adalah suatu persetujuan dari pihak berwenang (Pemerintah), yang oleh Undang-undang atau Peraturan Pemerintah diberikan hak kepadanya (Penguasa) untuk mengeluarkan

4 N.M. Spelt dan J.B.J.M. Ten Berge, disunting Philipus M. Hadjon, Pengantar Hukum Perizinan, Surabaya, Penerbit Yuridika, 1993, hlm. 127.

${ }^{5}$ Ibid.

${ }^{6}$ Van Der Pot dalam Utrecht dan Moh. Saleh Sjindang, 1985, Pengantar Hukum Administrasi Negara Indonesia, Cetakan kedelapan, Jakarta, Balai Buku Ichtiar, hlm. 128. 
Keputusan (Beschikking) baik dalam keadaan formal/tertentu maupun dalam keadaan biasa yakni di luar dari ketentuan aturan perundang-undangan yang berlaku.

Izin berupa keputusan dapat dikeluarkan oleh Pemerintah berdasarkan peraturan perundang-undangan yang bersifat formal dan berlaku dalam kurun waktu tertentu disebut sebagai keputusan tata usaha negara. Tetapi ada pula izin yang sifatnya sementara/biasa di luar ketentuan peraturan, dikeluarkan oleh yang berwenang, tidak mengikat dan tidak berlangsung lama.

Dapat pula dikatakan bahwa izin adalah salah satu instrumen yang biasanya paling banyak digunakan dalam hukum administrasi atau tata usaha negara. Dengan instrumen itu penguasa menjalankan tugasnya. Kewenangan dengan mengeluarkan izin dapat pula diartikan sebagai suatu persetujuan dari penguasa berdasarkan undang-undang atau peraturan pemerintah, dan untuk keadaan tertentu dapat saja menyimpang dari ketentuan peraturan perundangundangan.

Penetapan tata usaha negara berupa keputusan dalam rangka mengurus dan mengatur urusan rumah tangga sendiri yang menjadi hak otonomi daerah, sesuai amanah undang-undang. Oleh karenanya urusan lingkungan hidup yang ada di wilayah masing-masing daerah menjadi tanggungjawab daerah, tidak terkecuali dengan kelola sumberdaya alam yang ada di daerah. Artinya harus secara selektif mengeluarkan keputusan izin lingkungan yang menjadi bagian dari kinerja tata usaha daerah, dengan didasarkan kepada data yang ada di lapangan.

Selanjutnya pengertian Izin seperti dikemukakan dalam Pasal 1 angka 35 UUPPLH menyebutkan, bahwa Izin Lingkungan adalah "izin yang diberikan kepada setiap orang yang melakukan Usaha dan/atau Kegiatan yang wajib Amdal atau UKL-UPL dalam rangka perlindungan dan pengelolaan lingkungan hidup sebagai prasyarat memperoleh izin Usaha dan/atau Kegiatan”.

Pengertian Izin Lingkungan, disebutkan dalam Pasal 1 angka 1 PP Izin Lingkungan, adalah izin yang diberikan kepada setiap orang yang melakukan Usaha dan/atau Kegiatan yang wajib Amdal atau UKL-UPL dalam rangka perlindungan dan pengelolaan lingkungan hidup sebagai prasyarat memperoleh izin Usaha dan/atau Kegiatan.

Dasar hukum lain yang turut menunjang pelaksanaan Izin Lingkungan dapat dilihat dalam: 
1. Peraturan Menteri Lingkungan Hidup Nomor 5 Tahun 2012 tentang Kegiatan Wajib Amdal;

2. Peraturan Menteri Lingkungan Hidup Nomor 16 Tahun 2012 tentang Pedoman Penyusunan Dokumen Lingkungan Hidup;

3. Peraturan Menteri Lingkungan Hidup Nomor 17 Tahun 2012 tentang Pedoman Keterlibatan Masyarakat dalam Proses Amdal dan Izin Lingkungan;

4. Peraturan Menteri Lingkungan Hidup Nomor 8 Tahun 2013 tentang Tata Laksana Penilaian dan Pemeriksaan Dokumen Lingkungan Hidup serta Penerbitan Izin Lingkungan.

Kewajiban analisis terhadap dampak lingkungan memang sangat penting, terutama bentuk usaha dan/atau kegiatan yang akibatnya dapat mengubah bentuk lahan dan bentang alam. Atau proses kegiatan sangat potensial menimbulkan kerusakan dan pencemaran lingkungan hidup, termasuk pula yang dapat menimbulkan kemerosotan sumber daya alam dan daya dukung bumi. Untuk itu semua dibutuhkan analisis dampak lingkungan.

Untuk suatu Izin Lingkungan harus didahului dengan kajian mengenai dampak penting atas suatu Usaha dan/atau
Kegiatan yang direncanakan pada lingkungan hidup (Amdal). Kajian dari suatu perencanaan Usaha dan/atau Kegiatan sangat menentukan/diperlukan bagi proses pengambilan keputusan. Kajian mengenai dampak yang bakal terjadi apabila ternyata dapat menimbulkan perubahan terhadap lingkungan hidup, maka mensyaratkan mewajibkan kepada pelaku Usaha dan/atau Kegiatan untuk membuat penyusunan Amdal dan UKL-UPL. Apabila dalam penilaian dinyatakan memenuhi kelayakan lingkungan hidup maka secara prinsif akan diterbitkan Izin Lingkungan.

Sedangkan Upaya Pengelolaan Lingkungan dan Upaya Pemantauan Lingkungan Hidup (UKL-UPL), adalah pengelolaan dan pemantauan terhadap usaha dan/atau kegiatan yang tidak berdampak besar dan penting terhadap lingkungan hidup, namun diperlukan pula dalam proses pengambilan keputusan tentang penyelenggaraan Usaha dan/atau Kegiatan. Mengandung pula arti bahwa semua proses pelaksanaan yang dilakukan selalu berhubungan dengan ekosistem lingkungan hidup dan sumber daya alam. Sehingga kegiatan yang tidak berdampak penting karena tidak menimbulkan perubahan rona lingkungan hidup, cukup mewajibkan kepada pelaku Usaha 
dan/atau Kegiatan untuk menyusun dan memiliki rekomendasi UKL-UPL. Dan apabila proses penilaian dinyatakan layak barulah diterbitkan Izin Lingkungan.

Penyusunan oleh pemrakarsa harus dilakukan pada tahap perencanaan suatu Usaha dan/atau Kegiatan, dengan memberitahukan rencana lokasi, sesuai dengan rencana tata ruang, sehingga penyusunan Amdal harus dituangkan kedalam dokumen Amdal yang memuat pula Kerangka Acuan, Andal dan RKLRPL (Rencana Pengelolaan Lingkungan Rencana Pemantauan Lingkungan).

Kalau memperhatikan ketentuan di atas pada dasarnya peruntukkan izin lingkungan hanya diberikan kepada setiap usaha dan/atau kegiatan yang wajib Amdal atau UKL-UPL saja. Dalam arti Izin Lingkungan merupakan pelengkap yang pertama dan utama dalam hal urusan tata usaha negara yang harus didapatkan oleh pelaku usaha dan/atau kegiatan serta pemrakarsa untuk selanjutnya dijadikan sebagai prasyarat dalam memperoleh Izin Usaha dan/atau Kegiatan.

Untuk mendapatkan izin dimaksud maka proses keutamaan dalam Analisis Mengenai Dampak Lingkungan (Amdal), yang pada hakekatnya bertujuan untuk melakukan kajian-kajian terhadap dampak penting bagi lingkungan hidup atas direncanakannya suatu Usaha dan/atau
Kegiatan. Dengan maksud dan diperlukan bagi proses pengambilan keputusan untuk selanjutnya apakah layak/tidak diberikan izin bagi diselenggarakannya Usaha dan/atau Kegiatan dimaksud.

Maka untuk mendapatkan keputusan kelayakan lingkungan hidup dari setiap rencana Usaha dan/atau Kegiatan dimaksud, wajib dilengkapi dengan ketentuan Amdal. Dapat dipastikan bahwa Usaha dan/atau Kegiatan tersebut adalah memiliki lingkup usaha dan kegiatan berskala besar yang berdampak terhadap lingkungan hidup.

Dari kedua perangkat aturan yang mengatur Izin Lingkungan, apabila semua syarat telah dipenuhi dan selanjutnya Izin diterbitkan, maka kepada pemegang Izin Lingkungan ada lagi kewajiban lainnya, yakni kesanggupan untuk menyediakan dana penjaminan bagi pemulihan fungsi lingkungan hidup. Dana jaminan yang disediakan oleh pemegang izin, dimaksudkan untuk dan apabila pemrakarsa atau pelaku usaha dan/atau kegiatan setelah terjadi perubahan lingkungan hidup yang membawa dampak berupa kerusakan dan pencemaran.

\section{Izin Lingkungan Bagi Usaha dan/atau} Kegiatan Pertambangan

Pada hakekatnya setiap kegiatan penambangan akan selalu membawa 
kepada dampak positif dan negatif terhadap ekosistem lingkungan hidup, tatanan sosial, ekonomi, budaya, kearifan masyarakat lokal, adat-istiadat, dan kesehatan manusia, serta makhluk hidup lainnya. Begitu juga pengaruhnya dengan perubahan wilayah yang telah ditetapkan pemerintah.

Dampak dari setiap penambangan yang dijalankan akan merubah ekosistem lingkungan hidup yang awalnya alami menjadi tidak lagi alami. Tidak dipungkiri pula bahwa dengan dibukanya lahan bagi usaha dan/atau kegiatan pertambangan akan semakin memperlaju gerak pertumbuhan dan perkembangan di sektor pajak untuk pembangunan, bertambahnya anggaran pendapatan untuk belanja negara dan daerah, serta untuk infrastruktur yang membuka jarak keterisoliran antara desa dengan desa, dan antara kota dengan desa, serta membuka akses daerah terpencil.

Pemanfaatan sumber daya alam berupa batubara yang dewasa ini semakin luas diusahakan, sekarang masih menjadi sumber devisa Negara. Dengan dikuatkan dan dituangkannya ke dalam Pasal 28 Undang-Undang Nomor 4 Tahun 2009 tentang Pertambangan Mineral dan Batubara yang lazim disingkat UU. Minerba, menyebutkan antara lain bahwa tidak menutup kemungkinan yang semula menjadi Wilayah Pencadangan Negara, yang dicadangkan untuk kepentingan strategis nasional, akan berubah menjadi Wilayah Usaha Pertambangan Khusus, yang dapat diusahakan dengan mempertimbangkan pemenuhan baku industri dan energi dalam negeri, sumber devisa negara, kondisi wilayah di dasarkan pada keterbatasan sarana dan prasarana, berpotensi sebagai pusat pertumbuhan ekonomi. Sehingga perlu dikelola dan diawasi serapi mungkin.

Batubara yang ditambang tentu saja akan menimbulkan dampak besar dan penting terhadap lingkungan hidup dan kehidupan manusia. Lingkungan hidup dapat dipastikan berdampak terhadap kerusakan, berupa hancurnya struktur tanah, terjadi degradasi hutan dan semakin menipis cadangan hutan. Dampak banjir, udara semakin tercemar, serta terjadinya pemanasan global (Global Worming). Begitu pula dengan kandungan air sungai yang mengalami ketercemaran, keruh dan bau. Tidak hanya mengalami ketercemaran lingkungan hidup tetapi juga kerusakan ekosistem lingkungan sumber daya alam.

Untuk menghindari dampak negatif yang sangat luas dibutuhkanlah berbagai persyaratan. Dengan ketentuan izin yang menjadi bagian dari kinerja pemerintahan, harus menjadi tugas dan kewajiban Pemerintah baik di pusat 
maupun di daerah. Jadi dengan mengatur dan mengurus sumber kekayaan alam di wilayahnya adalah menjadi tanggungjawab masing-masing pemerintahan, di bidang tata usaha negara berupa penerbitan izin lingkungan.

Sekarang Izin Lingkungan pertambangan yang sudah diterbitkan, bolehkah ditolak keabsahannya karena sebab kekeliruan. Maka untuk sebabsebab tertentu Izin Lingkungan dapat dibatalkan apabila:

a. Persyaratan yang diajukan dalam permohonan izin mengandung cacat hukum, kekeliruan, penyalahgunaan serta ketidakbenaran dan/atau pemalsuan data, dokumen, dan/atau informasi;

b. Penerbitannya tanpa memenuhi syarat sebagaimana tercantum dalam keputusan komisi tentang kelayakan lingkungan hidup atau rekomendasi UKL-UPL; atau

c. Kewajiban yang ditetapkan dalam dokumen Amdal atau UKL-UPL tidak dilaksanakan oleh penanggungjawab usaha dan/atau kegiatan. (Pasal 37 Ayat (2) UUPPLH).

Persyaratan yang kemudian diketahui mengandung cacat hukum, atau ternyata bertentangan dengan penilaian dan keputusan komisi amdal, maka segala izin yang sudah dikeluarkan harus segera dibatalkan dan dicabut. Termasuk kewajiban yang dimuat dalam dokumen Amdal atau UKL-UPL yang dibuat oleh Pemrakarsa atau penanggungjawab usaha dan/atau kegiatan di bidang pertambangan, apabila ternyata tidak ditepati maka Izin Lingkungan batal demi hukum. Batal dalam arti berlaku untuk semua perizinan.

Pembatalan melalui keputusan tata usaha negara lazimnya bermula dari keberatan-keberatan yang disampaikan oleh masyarakat baik kolektif maupun individu. Keberatan karena bertentangan dengan hukum lingkungan atau ketentuan amdal, telah dirasakan dampak yang merugikan bagi kesehatan manusia, atau kerusakan dan pencemaran bagi lingkungan hidup itu sendiri. Jadi hakim tata usaha negara dapat membatalkan berlakunya suatu Izin Lingkungan, apabila terbukti penerbitan izin itu ternyata ditemui cacat hukum, ada kejanggalan, atau tidak sesuai prosedur karena tidak melibatkan peran serta masyarakat dalam pengambilan penilaian.

Jadi penyusunan dokumen Amdal pada hakekatnya dapat saja dimintakan bantuan orang lain yang lebih profesional. 
Dalam UU Minerba, mengatur pula tentang persoalan Izin yang sangat banyak ragam dan pula peruntukkannya. Persoalan yang sifatnya khusus karena menyangkut bidang industri tentu saja diprediksi akan lebih banyak mengandung resiko berupa dampak besar dan penting terhadap lingkungan, yang dapat merubah rona lingkungan. Oleh karena itu ada beberapa kriteria izin peruntukkan, serta harus diperhatikan persyaratannya.

Ketentuan Umum UU Minerba, ada menyebutkan berbagai macam izin:

1. Izin Usaha Pertambangan yang selanjutnya disebut IUP, adalah izin untuk melaksanakan usaha pertambangan;

2. IUP Eksplorasi adalah izin usaha yang diberikan untuk melakukan tahapan kegiatan penyelidikan umum, eksplorasi, dan studi kelayakan;

3. IUP Operasi Produksi adalah izin usaha yan diberikan setelah setelah pelaksanaan IUP Ekspolarasi untuk melakukan tahapan kegiatan operasi produksi;

4. Izin Pertambangan Rakyat, yang selanjutnya disebut IPR adalah izin untuk melaksanakan usaha pertambangan dalam wilayah pertambangan rakyat dengan luas wilayah dan investasi terbatas;
5. Izin Usaha Pertambangan Khusus, yang selanjutnya dengan IUPK adalah izin untuk melaksanakan usaha pertambangan di wilayah izin usaha pertambangan khusus;

6. IUPK Eksplorasi adalah izin usaha yang diberikan untuk melakukan tahapan kegiatan penyelidikan umum, eksplorasi, dan studi kelayakan di wilayah izin usaha pertambangan khusus;

7. IUPK Operasi Produksi adalah izin usaha yang diberikan setelah selesai pelaksanaan IUPK Eksplorasi untuk melakukan tahapan kegiatan operasi produksi di wilayah izin usaha pertambangan khusus.

Setelah diterbitkan PP Izin Lingkungan, maka setiap aktivitas dalam berbagai usaha dan/atau kegiatan yang pada dasarnya menimbulkan dampak terhadap lingkungan harus dilakukan dengan baik berdasarkan aturan yang berlaku.

Menyangkut batubara yang ditambang adalah merupakan bahan galian industri, demikian Sukandarrumidi memaparkan tentang bahan galian strategis. $^{7} \quad$ Untuk mewujudkan hal

\footnotetext{
${ }^{7}$ Sukandarrumidi, Bahan Galian Industri, Yogyakarta, Gadjah Mada University Press, 2004, hlm. 1-2.
} 
tersebut telah ditetapkan pengusahaan pertambangan bahan galian golongan A dan B yang diatur dalam bentuk Kuasa Hukum (KP). Sedang untuk bahan galian golongan C cukup dalam bentuk Surat Izin Pertambangan Daerah (SIPD).

Selanjutnya kalau memperhatikan ketentuan mengenai izin seperti dikemukakan dalam UU. Minerba dalam Pasal 65 Ayat (1), dapat di lihat tentang persyaratan perizinan usaha pertambangan, yakni setiap badan usaha, koperasi, dan perseorangan yang melakukan usaha pertambangan wajib memenuhi persyaratan administratif, persyaratan teknis, persyaratan lingkungan, dan persyaratan finansial.

Tetapi jika memperhatikan persyaratan lingkungan, yang artinya tidak lepas dengan semua yang telah disebutkan dan disyaratkan dalam UUPPLH. Yaitu berkenaan dengan kegiatan usaha dan/atau kegiatan lainnya yang berdampak penting terhadap lingkungan hidup, maka wajib dilengkapi dengan Amdal.

Undang-Undang Minerba yang telah disempurnakan, bahkan menekankan, bahwa pembangunan pertambangan harus dapat menyesuaikan kondisi atau beradaptasi dengan perubahan lingkungan strategis, perkembangan teknologi, tuntutan peningkatan dan peran serta swasta dan masyarakat.

Dalam Usaha dan/atau Kegiatan di bidang pertambangan, jelas menyangkut ekosistem lingkungan dan sumber daya alam, maka wajib memiliki Amdal atau UKL-UPL, karena merupakan prasyarat untuk mendapatkan Izin Lingkungan. Amdal atau UKL-UPL yang pada dasarnya harus bersamaan dengan pengajuan permohonan Izin, dimuat dalam satu dokumen untuk segera dilakukan penilaian oleh tim penilai. Penilaian untuk suatu rencana kegiatan dikatakan layak, atau tidak layak, maka setiap pelaku Usaha dan/atau Kegiatan harus lebih dulu melakukan kajian dan analisis berkenaan dengan dampak. Disini letak pentingnya Amdal dan UKL-UPL agar dampak besar dan penting bagi lingkungan tidak menimbulkan persoalan kerusakan dan ketercemaran yang mengarah kepada kerugian umat manusia.

Sebagai gambaran di bawah ini dapat dilihat dampak positif dan negatif dikembangkannya kegiatan pertambangan batubara, sebagai berikut:

Dampak Positif yang diharapkan:

1. Masyarakat diberi kesempatan untuk bekerja, terutama masyarakat sekitar yang membutuhkan pekerjaan; 
2. Mendorong nilai jual harga tanah rakyat;

3. Membuka akses desa dan kota;

4. Membuka akses infrastruktur berupa sarana jalan, jembatan;

5. Menekan arus urbanisasi;

6. Dapat membantu sarana pendidikan, keagamaan, dan kesehatan.

Sedangkan dampak Negatif, bakal terjadi:

1. Kerusakan dan pencemaran tanaman tak bisa dielakkan;

2. Tercemar air sungai; dan berkurang populasi jenis hewan;

3. Peralihan mata pencaharian; dari masyarakat agraris ke masyarakat industri, yakni meninggalkan dan menerlantarkan lahan pertanian;

4. Rentan banjir;

5. Meningkatnya penyakit ISPA;

Namun harus dipahami kalau negara Indonesia dewasa ini tak mungkin bisa mengelak dalam menyongsong gerakan globalisasi dan modernisasi. Langkah pemerintah adalah juga sebagai perwujudan untuk meningkatkan kesejahteraan dan kemakmuran rakyat banyak. Apalagi usaha pertambangan yang termasuk kegiatan industri. Dengan pengelolaan yang seimbang dan hasilnya bagi pelaksanaan pembangunan untuk menuju masyarakat yang berkeadaban. Maka dengan didukung aset sumber daya alam nonhayati yang berlimpah, sangat menunjang kegiatan pembangunan nasional dan kesejahteraan rakyat.

Jadi meskipun ada hambatanhambatan haruslah dimaknai dan dijadikan sebagai suatu tantangan yang harus dihadapi dengan arif dan bijak. Terlebih lagi semua dampaknya sudah diprediksi. Maka langkah-langkah yang ditempuh harus berdasarkan prinsif pembangunan yang berkelanjutan dan ramah lingkungan.

Kekayaan alam yang menjadi modal bagi pembangunan Indonesia tidak boleh disia-siakan. Untuk perwujudan tujuan yang dicita-citakan ada faktor pendukung dan penghambat yang saling berhadapan. Faktor pendukung, antara lain:

a. Indonesia kaya sumber daya alam nonhayati baik terbarukan maupun yang tidak terbarukan;

b. Juga kaya dengan berbagai aneka species hayati baik di darat maupun di laut;

c. Geografis negara Indonesia berada pada posisi sentral, sangat mudah dan lancar di tempuh, serta aman;

d. Sumber daya manusia dan tenaga kerja Indonesia banyak; 
e. Kebijakan pemerintah jelas, transparan dan mengutamakan kepastian hukum;

Sedangkan faktor Penghambat diataranya:

a. Sosialisasi tentang Amdal dan membuat dokumen Amdal masih kurang diperhatikan;

b. Penyusun Amdal yang memiliki sertifikat kompetensi masih sedikit;

c. Mutu barang masih kalah bersaing;

d. Kurang memadainya sarana sosialisasi dan promosi;

e. Sarana dan prasarana yang masih belum merata di Indonesia;

Sehubungan dengan maksud di atas, maka ketentuan izin yang menjadi wewenang pemerintahan, harus menjadi tugas dan kewajiban Pemerintah baik di pusat maupun di daerah. Yakni dengan mengatur dan mengurus sumber kekayaan alam yang merupakan tanggugngjawab masing-masing di bidang tata usaha negara. Dengan menjalankan tugas dan kewajiban tersebut, Menteri, Gubernur, Bupati/Walikota sesuai kewenangannya wajib menolak permohonan izin lingkungan apabila permohonan izin tidak dilengkapi dengan Amdal atau UKL-UPL. (Pasal 37 ayat (1) UUPPLH).

Kecerobohan pembuatan dan penyusunan dokumen Amdal dan UKL-
UPL tidak perlu terjadi. Begitu pula segala bentuk penilaian oleh tim komisi kelayakan lingkungan harus harmonis dan sinkron dengan telaah yang dilakukan Pemerintah dan Pemerintah Daerah. Ketika akan menerbitkan Izin Lingkungan maka segala bentuk keputusan yakni berupa izin resmi harus memenuhi asas kepastian hukum. Artinya untuk mencapai asas legalitas maka setiap tindakan yang dilakukan pemerintah harus bersifat cermat dan hati-hati. Jangan sampai terjadi izin yang diterbitkan kemudian dibatalkan karena alasan keliru.

Sesungguhnya pembatalan dapat saja dilakukan melalui keputusan tata usaha negara lazimnya bermula dari keberatan-keberatan yang disampaikan oleh masyarakat baik kolektif maupun individu. Keberatan karena bertentangan dengan hukum lingkungan atau ketentuan amdal, atau telah dirasakan dampak yang merugikan bagi kesehatan manusia atau kerusakan dan pencemaran bagi lingkungan hidup itu sendiri. Maka penggugat/class action menyampaikan keberatannya kepada Pengadilan Tata Usaha Negara.

Dengan berbagai alasan dan bukti yang diajukan di persidangan, boleh jadi hakim akan membatalkan izin lingkungan yang telah diterbitkan baik oleh Menteri,

Gubernur, Bupati/Walikota. Ini 
menunjukkan apa yang tadinya menjadi kewenangan Menteri, Gubernur, Bupati/Walikota untuk penerbitan suatu Izin Lingkungan, ternyata bisa dibatalkan oleh hakim tata usaha negara, apabila diketahui penerbitan izin itu ternyata ditemui cacat hukum, ada kejanggalan, atau tidak sesuai prosedur karena tidak disertakannya masyarakat selaku anggota Komisi penilai.

Kelayakan dari setiap rencana Usaha dan/atau Kegiatan didasarkan pada dipenuhinya ketentuan Amdal atau UKLUPL. Dan layak lingkungan atas hasil penelitian dan penilaian Komisi Penilai Amdal. Tidak disitu saja ternyata untuk memperoleh Izin Lingkungan, pemrakarsa dan penanggungjawab usaha wajib pula mencantumkan persyaratan seperti dimuat dalam keputusan kelayakan lingkungan hidup atau rekomendasi UKLUPL yang diputuskan oleh pejabat yang berwenang. (Pasal 37 Ayat UUPPLH).

Selanjutnya untuk keamanan dan kelancaran pelaksanaan pemulihan berupa reklamasi dan reboisasi, maka pemrakarsa atau pelaku usaha dan/atau kegiatan wajib menyiapkan dana penjaminan yang disimpan di bank pemerintah yang ditunjuk oleh Menteri, Gubernur, Bupati/Walikota sesuai dengan kewenangannya. Dengan tujuan apabila pemulihan fungsi lingkungan hidup tidak dilakukan oleh pemrakarsa atau pelaku kegiatan, maka dana penjaminan tadi wajib digunakan untuk biaya pemulihan fungsi lingkungan hidup (Pasal 54 dan Pasal 55 UUPPLH).

\section{Keterlibatan Masyarakat Sebagai}

\section{Anggota Komisi Penilai Amdal}

Penyusunan dokumen Amdal oleh Pemrakarsa wajib melibatkan masyarakat. Sebelumnya dilakukan dulu dengan penyusunan dokumen Kerangka Acuan. Masyarakat yang dilibatkan berhak mengajukan saran, pendapat dan tanggapan terhadap rencana Usaha dan/atau Kegiatan. Pelibatan masyarakat harus dilakukan berdasarkan prinsip pemberian informasi yang transparan dan lengkap serta diberitahukan sebelum kegiatan dilaksanakan.

Dalam Pasal 9 PP Izin Lingkungan menyebutkan bahwa, masyarakat yang diikutsertakan dalam menyusun dokumen Amdal, terutama:

a. Yang terkena dampak ;

b. Pemerhati lingkungan hidup; dan/atau

c. Yang terpengaruh atas segala bentuk keputusan dalam proses Amdal.

Diikutkannya masyarakat dengan cara diumumkan baik lisan maupun 
tertulis, dan dilakukan dalam jangka waaktu 10 hari sejak pengumuman dikeluarkan.

Mengingat pelibatan masyarakat dilakukan sebelum penyusunan dokumen, berarti masyarakat hanya sekedar mengajukan saran, dan tanggapan terhadap rencana Usaha dan/atau Kegiatan. Tidak melihat kepada bentuk rancangan bangunnya seperti apa. Maka yang demikian ini sulit memberikan penilaian dan tanggapan.

Selanjutnya jika memperhatikan persyaratan penyusunan Amdal dan UKLUPL yang diatur oleh peraturan Izin Lingkungan, maka untuk memperoleh Izin Usaha dan/atau Kegiatan harus lebih dahulu ada izin lingkungan. Sedangkan Izin Lingkungan diperoleh setelah dipenuhinya ketentuan Amdal, yang wajib dimuat dalam dokumen Amdal dengan disertai Kerangka Acuan (KA); Analisis Dampak Lingkungan (Andal); dan Rencana Pengelolaan Lingkungan dan Rencana Pemantauan Lingkungan (RKLRPL). Disyaratkan pula penyusunan dokumen Amdal dan UKL-UPL harus dilibatkan peran serta masyarakat.

Sayangnya pelibatan masyarakat hanya bersifat seremonial saja, karena pelibatan masyarakat dalam menilai semua rencana dan penyusunan dokumen Amdal dan UKL-UPL, dalam UUPPLH dan PP Izin Lingkungan tidak dikemukakan secara rinci.

Sedangkan proses penyusunan dokumen Amdal dan UKL-UPL yang harus ditempuh dalam pencapaian Izin Lingkungan dirasakan cukup panjang.

Apabila keikutsertaan masyarakat dan pemerhati lingkungan hidup, nantinya akan diketahui apa saja yang diduga terdampak atas segala bentuk keputusan dalam proses Amdal, maka seyogyanya saran, pendapat, dan keberatan sesegeranya dianalisis oleh Pemrakarsa/penanggung-jawab yang dituangkan dalam aturan hukum.

UUPPLH yang mencanangkan pentingnya perlindungan dan pengelolaan lingkungan hidup ditindaklanjuti dengan pelaksanaan dari ketentuan PP. Izin Lingkungan. Sebagai aturan pelaksana harus ada unsur penekanan yang wajib dilakukan oleh pemrakarsa, Pemerintah dan Pemerintah Daerah dalam menjaga dan memelihara ekosistem lingkungan hidup terhadap semua usaha dan/atau kegiatan. Mengingat persoalan lingkungan hidup sangat peka dirasakan langsung bagi kehidupan manusia maka perlu ada ketegasan dari berbagai aturan tersebut..

Masyarakat yang terkena dampak selain sebagai Anggota Komisi Penilai, juga sebagai pelaku dan pengawas lingkungan, wajib menjaga lingkungan 
hidup. Lingkungan kehutanan misalnya, yang semula menghijau, kini semakin menipis karena maraknya pembalakan liar yang dilakukan oleh orang-orang yang ingin mencari keuntungan sepihak namun menghindar dari tanggungjawab. Termasuk pula bagi pemegang izin HPH, yang melakukan penebangan di luar dari areal izin HPH yang semestinya, atau tidak melakukan penghijauan kembali. Karena semakin rusak dan berkurang cadangan hutan, akibatnya tak kuasa lagi bagi hutan menyerap energi panas matahari. Bumi juga semakin terkuras akibat ekploitasi dan eksplorasi besarbesaran atas kandungan batubara, timah, emas, dan lain-lain dalam lingkup kawasan hutan.

Oleh sebab itu Pemerintah dalam rangka melindungi bumi, air, dan semua kekayaan alam yang terkandung di dalamnya, harus dikuasai dan dijaga oleh negara untuk sebesar-besarnya kemakmuran rakyat Indonesia. Dalam arti wajib melaksanakan amanah UndangUndang Dasar untuk kemakmuran rakyat Indonesia. Menguasai oleh negara dalam arti mengurus dan mengatur. Menguasai berupa mengurus dapat dipahamkan bahwa negara wajib memberikan perlindungan, menjaga dan mengelola agar keberadaan kekayaan alam kita tidak cepat rusak dan punah. Rusak tidak lagi bisa dimanfaatkan, tidak ada lagi keuntungan yang didapatkan. Sedangkan punah tidak lagi bisa diharapkan karena tidak ada lagi yang tersisa.

Sebagai contoh untuk menghindari terjadinya kerusakan setelah penambangan khususnya di areal kehutanan, adalah kewajiban melakukan reklamasi dan reboisasi pasca tambang seperti diisyaratkan PP Nomor 78 Tahun 2010 tentang Reklamasi dan Pasca Tambang.

Selanjutnya menguasai dalam arti mengatur artinya pemerintah mengatur dan membagi areal lahan dari semua kegiatan dan usaha. Semua jenis usaha dan semua jenis kegiatan yang menyangkut sumber daya alam maka pemerintahlah yang membagi dan menentukan zona dan peruntukkannya. Tidak terkecuali yang mengantongi izin resmi, maka setiap usaha dan/atau kegiatan, dilakukan harus ditempuh dan berdasarkan ketentuan hukum yang berlaku. Yakni dengan menyampaikan rencana dan keinginan untuk melakukan Usaha dan/atau Kegiatan, dan setiap pengusaha atau pemrakarsa wajib secara formal menempuh jalur yang sudah diatur dan ditentukan oleh Pemerintah berdasarkan peraturan perundangundangan. 
Yang demikian ini menunjukkan bahwa betapa pentingnya Izin Lingkungan. Penting bagi mereka yang ingin berusaha di wilayah Republik ini. Begitu pula di sisi lain betapa pentingnya untuk menjaga kelestarian lingkungan hidup agar tetap selaras, serasi dan seimbang. Karena dengan keselarasan, keserasian dan keseimbangan itu akan menciptakan ekosistem lingkungan yang harmonis dengan kehidupan manusia.

Persoalan Izin Lingkungan seyogyanya pelibatan masyarakat sebagai anggota Komisi Penilai Amdal diberi pula peran sebagai pengawas langsung. Masyarakat sekitar selaku terdampak berhak menolak setiap rencana usaha dan/atau kegiatan yang akan dilakukan di wilayahnya.apabila di duga menimbulkan kerugian dan kerusakan. Seyogyanya kalimat penolakan dicantumkan dalam pasal UUPPLH dan dalam PP. Izin Lingkungan. Karena kata "menolak" mempunyai makna yang sangat tegas, tidak hanya penolakan terhadap dokumen Amdal yang telah disusun, tetapi juga terhadap rencana pembuatan Amdal dan UKL-UPL.

Penolakan berlaku apabila prinsip pemberian informasi yang transparan dan lengkap tidak dijalankan sebagaimana mestinya sebelum kegiatan dilaksanakan.
Namun perlu pula diketahui kalau masyarakat sekarang ini juga sangat membutuhkan pekerjaan untuk kondisi ekonomi yang lebih baik demi kesejahteraan. Mengingat lapangan pekerjaan yang diharapkan dari pemerintah jarang didapatkan. Andainya ada maka terjadi pergulatan persaingan untuk menperoleh lowongan pekerjaan. Itupun tidak banyak yang dibutuhkan. Terjadilah pengangguran dimana-mana, karena kalah bersaing, atau karena persyaratan yang diminta tidak lengkap.

Sekarang dengan semakin kuat keinginan pengusaha menanam investasi, akan membuka peluang lapangan pekerjaan di sektor usaha dan kegiatan industri. Pemerintah membuka peluang berdasar peraturan sebagai pedoman pelaksananya. Dengan memberi kesempatan berusaha kepada pihak swasta atau para investor di semua sektor usaha, tidak terkecuali khususnya di bidang industri penambangan batubara yang dewasa ini semakin luas bergerak. Artinya dengan dibuka peluang mengembangkan usaha, pihak investor akan memanfaatkan kesempatan berusaha yang juga akan berdampak kepada penyerapan tenaga kerja lokal.

Dengan dibukanya kegiatan usaha dan/atau kegiatan lain, khususnya penambangan batubara, maka Pemerintah 
akan terbantu untuk mengurangi angka pengangguran. Masyarakatpun terbantu yang membutuhkan pekerjaan. Tapi pada sisi lainnya para investor/pelaku usaha juga harus terbentur dan berhadapan dengan berbagai persyaratan jika usaha yang dilakukan berdampak besar dan penting terhadap lingkungan. Yakni harus mendapatkan terlebih dahulu Izin Lingkungan.

Lalu bagaimana jika dilakukan dengan pendekatan sosial mengingat masyarakat sangat membutuhkan pekerjaan untuk suatu penghidupan yang layak.

Kalau memperhatikan substansi pasal yang dimuat dalam aturan perundangan di bidang lingkungan hidup dan sumber daya alam, termasuk pula PP Izin Lingkungan, ternyata tidak ditemukan tentang pengaturan kewenangan Pemerintah/Pemerintah Daerah, dalam hal membolehkan untuk menerbitkan Izin Lingkungan. Dispensasi karena permintaan masyarakat setempat yang dilakukan sebagai pendekatan sosial kemasyarakatan.

Jika diperhatikan bahwa dengan unsur dilibatkannya masyarakat ke dalam pembuatan Amdal hanyalah untuk meminta dukungan dan persetujuan saja. Artinya tanpa harus memerinci persyaratan yang disodorkan, namun dukungan masyarakat itu menjadi konsekuensi bahwa masyarakat telah setuju bahwa Amdal tidak membawa dampak besar dan penting yang bisa merugikan kehidupan masyarakat sekitar.

\section{PENUTUP}

\section{Kesimpulan}

1. Ketentuan Amdal dan UKL-UPL dibutuhkan sebagai kajian terhadap akibat yang akan terjadi terhadap rona lingkungan hidup. Maka kewajiban untuk membuat dokumen Amdal dan penyusunan UKL-UPL harus dilakukan oleh pemrakarsa atau pelaku usaha untuk memperoleh Izin Lingkungan. Izin Lingkungan dapat dimaknai sebagai pembuka jalan bagi izin-izin lainnya yang akan dimohonkan, dan selanjutnya dengan izin tersebut pemrakarsa atau pengusaha boleh menjalankan usaha atau melakukan kegiatan sesuai peruntukkan izin tersebut.

2. Penambangan batubara ternyata berdampak kepada perubahan rona lingkungan hidup. Untuk mengurangi dampak negatif pada lingkungan, maka Izin Lingkungan mutlak berlaku sebagai izin Prinsif yang wajib dimiliki dalam setiap usaha dan/atau kegiatan. Oleh 
sebab itu UUPPLH yang ditindak lanjuti dengan diterbitkannya PP. Izin Lingkungan, menekankan bahwa setiap Usaha dan/atau Kegiatan yang akan dilakukan harus lebih dahulu memiliki Izin Lingkungan.

3. Peran masyarakat dibutuhkan untuk memberikan penilaian terhadap dokumen Amdal dari rencana usaha dan/atau kegiatan, berupa saran dan tanggapan untuk menentukan kelayakan atau ketidaklayakan lingkungan. Sebagai anggota Komisi Penilai Amdal yang ditunjuk dari wakil masyarakat yang akan terkena dampak, sehingga keberatankeberatan yang muncul dari masyarakat menjadi pertimbangan dan penilaian mutlak bagi Pemerintah/Pemerintah Daerah sesuai kewenangannya masingmasing untuk penerbitan Izin Lingkungan.

\section{Saran}

1. Prosedur dan tata cara untuk memperoleh Izin Lingkungan yang disebutkan dalam UUPPLH dan PP Izin Lingkungan perlu disosialisasikan. Agar para pelaku
Usaha mengerti dan dapat melaksanakannya dengan lancar.

2. Izin Lingkungan yang diberikan kepada usaha penambangan batubara wajib diawasi oleh Pemerintah/Pemerintah Daerah, agar dampak besar dan penting berupa kerusakan dan pencemaran lingkungan hidup dapat dicegah.

3. Harus diberi dasar hukum berupa penolakan masyarakat terhadap semua rencana kegiatan atau dokumen Amdal yang dianggap merusak lingkungan dan merugikan masyarakat. Demikian pula pengawasan masyarakat harus diberi dasar hukumnya.

\section{DAFTAR PUSTAKA}

\section{Buku}

Danusaputro, Munadjat, 2001, Hukum Lingkungan Buku I: Umum, Binacipta, Bandung.

N.M. Spelt dan J.B.J.M. Ten Berge, disunting Philipus M. Hadjon, 1993, "Pengantar Hukum Perizinan”, Yuridika, Surabaya.

Soemarwoto, Otto, 1989, Pembangunan dan Ekologi Lingkungan, Alumni, Bandung.

Sukandarrumidi, 2004, Bahan Galian Industri, Gadjah Mada University Press, Yogyakarta. 
Salim, H, H.S., 2007, Hukum Pertambangan di Indonesia, PT. Raja Grafindo Persada, Jakarta.

Takdir, Rahmadi, 2011, Hukum Lingkungan di Indonesia, PT. Raja Grafindo Persada, Jakarta.

\section{Peraturan Perundang-Undangan}

Undang-Undang Dasar Negara RI Tahun 1945.

Undang-Undang Nomor 41 Tahun 1999 jo Undang-Undang Nomor 19 Tahun 2004 tentang Kehutanan.

Undang-Undang Nomor 4 Tahun 2009 tentang Pertambangan Mineral dan Batubara.

Undang-Undang Nomor 32 Tahun 2009 tentang Perlindungan dan Pengelolaan Lingkungan Hidup.

Peraturan Pemerintah Nomor 27 Tahun 2012 tentang Izin Lingkungan.

\section{Makalah}

Kementerian Kehutanan RI, "Save Kalimantan Save Indonesia", Materi Seminar Memperingati Hari Bumi, di Banjarmasin, 21 April 2012

\section{Internet}

PP. Izin Lingkungan Rentan di Judicial Review, www.hukumonline.com, diakses tanggal 11 Desember 2017 
